\section{Plant Spacing Influences Watermelon Yield and Yield Components}

\author{
D.S. NeSmith \\ University of Georgia, Georgia Station, Griffin, GA 30223-1797 \\ Additional index words. density, fruit weight, plant population
}

\begin{abstract}
Watermelon [Citrullus lanatus (Thunb.) Matsum \& Nakai] cultivars StarBrite and Crimson Sweet were grown during 1991 and 1992 in rows $1.5 \mathrm{~m}$ apart at plant spacings of $0.9,1.5$, or $2.2 \mathrm{~m}$. Total fruit yield, marketable fruit yield, fruit-weight distribution, and estimated gross returns were determined for each spacing treatment. Total and marketable fruit yields were greater overall for 'StarBrite' than for 'Crimson Sweet'. Except for 1991 'Crimson Sweet' yields, marketable fruit yields per unit land area increased $29 \%$ to $34 \%$ as plant spacing decreased from 2.2 to $0.9 \mathrm{~m}$. The yield component contributing the most to increased yields with high-density plantings was increased fruit count per unit land area. Average fruit weight responded only slightly to decreased plant spacing. Fruitweight distribution on a relative frequency scale was stable regardless of plant spacing or production year. The potential for increasing gross returns per unit land area exists by increasing watermelon plant populations beyond the current Georgia recommendation of 2500 to 3000 plants/ha.
\end{abstract}

There are many reports and reviews on the theoretical aspects of the relationship between crop yield and plant population density (Pant, 1979; Stang et al., 1979; Thomley, 1983; Willey and Heath, 1969). In general, increasing a plant population produces a greater biological yield per unit land area for most crops up to some upper limit or threshold density for the species, after which further increases in plant density either maintain the same yield or cause yield decline (Weiner, 1990; Willey and Heath, 1969). However, the effect of plant population on economic yield is not as straightforward. To achieve the highest yield of economic product per unit land area, crops should intercept solar radiation fully during the growth stage, when photosynthesis contributes carbohydrates to the economic product (Hall, 1990). The threshold plant population beyond which yield does not increase depends on environmental factors (Dweikat and Kostewicz, 1989; Thomley, 1983; Weiner, 1990). Also, plant population can influence crop $\times$ pest interactions. For instance, a closer plant spacing may

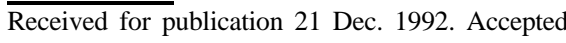
for publication 2 May 1993. A contribution of the Univ. of Georgia Agricultural Experiment Station, Georgia Station, Griffin. This research was supported by state and Hatch Act funds allocated to the Georgia Agricultural Experiment Station and by grant funds received from Asgrow Seed Co. The cost of publishing this paper was defrayed in part by the payment of page charges. Under postal regulations, this paper therefore must be hereby marked advertisement solely to indicate this fact. give crops a competitive advantage over weeds or provide ecological weed control (Auld et al., 1987; Weiner, 1990; Zimdahl, 1980). Increased plant density may discourage colo- nization by certain insects or reduce the percentage of insect-damaged plants (Power and Kareiva, 1990). In terms of disease pressure, high-density plantings may cause more rapid dissemination of certain pathogens, or, as with insect damage, there may be a reduced percentage of the population that is infected by certain other diseases (Mundt, 1990). Additionally, $\mathrm{C}$ partitioning is not constant as planting density changes; thus, an optimum density for vegetative growth is not necessarily the optimum density for fruit yield (Harper, 1977).

For fresh vegetable crops, product quality must be considered when examining the effects of plant population on yield. Several investigations have revealed increased marketable vegetable crop yields per unit land area as plant population increases (Cantliffe and Phatak, 1975; Knavel, 1991; Stoffella and Bryan, 1988; Stoffella et al., 1988; Widders and Price, 1989). However, there is a paucity of information concerning the influence of plant population on watermelon yield and yield components, particularly for some of the new hybrid cultivars that are available to growers (Brinen et al., 1979). The recommended plant population density for Georgia watermelons is 2500 to 3000 plants/ha (Granberry et al., 1986). This density is less than that reported to have increased marketable watermelon yields else-
Table 1. Total and marketable fruit count, fruit weight, and average individual fruit weight of 'StarBrite' and 'Crimson Sweet' watermelons grown at three plant spacings during 1991 and 1992.

\begin{tabular}{|c|c|c|c|c|}
\hline \multirow{2}{*}{$\begin{array}{l}\text { Plant } \\
\text { spacing (m) }\end{array}$} & \multicolumn{2}{|c|}{ StarBrite } & \multicolumn{2}{|c|}{ Crimson Sweet } \\
\hline & 1991 & 1992 & 1991 & 1992 \\
\hline \multicolumn{5}{|c|}{ Fruit/ha $(1000 \mathrm{~s})$} \\
\hline 0.9 & 10.75 & 19.07 & 5.75 & 17.57 \\
\hline 1.5 & 8.62 & 14.17 & 4.00 & 12.42 \\
\hline 2.2 & 6.50 & 13.00 & 3.75 & 10.75 \\
\hline Linear significance & $*$ & $*$ & NS & ** \\
\hline \multicolumn{5}{|c|}{ Total fruit $w t\left(t \cdot h a^{-1}\right)$} \\
\hline 0.9 & 69.7 & 154 & 27.0 & 125 \\
\hline 1.5 & 59.9 & 109 & 20.1 & 86.8 \\
\hline 2.2 & 46.6 & 111 & 22.7 & 79.2 \\
\hline Linear significance & * & * & NS & ** \\
\hline \multicolumn{5}{|c|}{ Average fruit $w t(\mathrm{~kg} /$ fruit $)$} \\
\hline 0.9 & 7.4 & 8.0 & 5.3 & 7.1 \\
\hline 1.5 & 7.1 & 7.7 & 5.7 & 7.0 \\
\hline 2.2 & 7.8 & 8.5 & 7.0 & 7.4 \\
\hline Linear significance & NS & NS & ** & NS \\
\hline \multicolumn{5}{|c|}{ Marketable fruit wt $\left(t \cdot h a^{-t}\right)$} \\
\hline 0.9 & 49.7 & 125 & 12.3 & 88.2 \\
\hline 1.5 & 42.8 & 84.1 & 11.3 & 60.5 \\
\hline 2.2 & 37.2 & 96.9 & 14.6 & 65.6 \\
\hline Linear significance & * & * & NS & * \\
\hline \multicolumn{5}{|c|}{ Marketable fruit/ha $(1000 s)$} \\
\hline 0.9 & 5.64 & 12.56 & 1.54 & 9.23 \\
\hline 1.5 & 4.61 & 8.72 & 1.28 & 6.92 \\
\hline 2.2 & 4.10 & 9.49 & 1.54 & 7.18 \\
\hline Linear significance & $*$ & * & NS & $*$ \\
\hline
\end{tabular}

Ns, **** Nonsignificant or significant at $P \leq 0.05$ or 0.01 , respectively. 
where (Brinen et al., 1979). The objective of this research was to examine the influence of plant spacing on yield and yield components using a traditional open-pollinated watermelon cultivar (Crimson Sweet) and a new hybrid cultivar (StarBrite).

Experiments were conducted at Griffin, Ga., during 1991 and 1992 on a Cecil sandy clay loam (clayey, kaolinitic, thermic Typic Hapludult). On 31 May 1991 (day of year: 151) and 12 May 1992 (day of year: 133), 4week-old 'StarBrite' and 'Crimson Sweet' watermelon transplants were planted in the field at several plant spacings. A $2 \times 3$ factorial arrangement of treatments within a randomized complete block with three replications was used. Rows were $1.5 \mathrm{~m}$ apart for each plot, and in-row plant spacings were $0.9,1.5$, or 2.2 $\mathrm{m}$, a configuration resulting in plant populations of 7410, 4444, and 3030 plants/ha, respectively. Plots were six rows wide by $13 \mathrm{~m}$ long during 1991 and four rows wide by $13 \mathrm{~m}$ long during 1992. Transplants were handplanted and watered. Before transplanting them, a $10 \mathrm{~N}-4.4 \mathrm{P}-8.3 \mathrm{~K}$ fertilizer was incorporated at $560 \mathrm{~kg} \cdot \mathrm{ha}^{-1}$. An additional $78 \mathrm{~kg} \mathrm{~N}$ (as ammonium nitrate)/ha was surfacesidedressed weeks after transplanting. Weeds were controlled using a combination of recommended herbicides and hand weeding. Recommended insect and disease control measures also were used. Overhead-sprinkler irrigation was used to supplement rainfall. A hive of bees was located near the research plots each year.

A once-over harvest was made for the two experiments on 20 Aug. 1991 (day of year: 232) and 29 July 1992 (day of year: 211) to determine the distribution of fruit weights, independent of time. Watermelons were harvested from the two center rows of each plot in a total harvest area of $39 \mathrm{~m}^{2}$. All fruit in the harvest area were picked and weighed individually. Soluble solids concentration (SSC) was measured in all fruit in 1991 and in a subsample in 1992. These data revealed that, in general, fruit weighing $>5 \mathrm{~kg}$ had an SSC $>9 \%$, a result indicating a sweetness level between "good" and "very good" (Hurst, 1988). Fruit weighing $\geq 6.8 \mathrm{~kg}$ were considered marketable. Data -were tested using analysis of variance to determine the significance of cultivar and spacing main effects and their interaction on various yield components. Regression was performed for each cultivar to determine the effects of plant spacing on crop attributes of interest. Gross returns were calculated using a regression equation obtained for marketable yield to predict yield for a particular plant spacing and by multiplying this yield by the 5-year average price of $\$ 0.13 / \mathrm{kg}$ fruit weight (Mizelle, 1990). Additionally, fruitweight class intervals of $2 \mathrm{~kg}$ were constructed for the individual fruit-weight data. The relative frequency in each class interval, based on fruit count, was calculated. These data were plotted as cumulative relative frequency of the fruit count for individual fruit-weight classes.

Cultivars differed $(P \leq 0.05)$ in fruit count, total fruit weight, and average fruit weight during both years, but there were no signifi- cant cultivar $\times$ spacing interactions. 'Crimson Sweet' yielded less than 'StarBrite during both years (Table 1). The cultivar difference likely was due to overall increased plant vigor and more uniform growth and fruit set of 'StarBrite' compared to those of 'Crimson Sweet' (Granberry, 1988).

Yields during 1991 were substantially lower than during 1992. The major yield component contributing to the yield differences between years was greater fruit counts during 1992, although average fruit weights were slightly higherduring 1992. The 1991 crop was planted later in the growing season than the 1992 crop (day of year 151 vs. 133), and there may have been some decrease in fruit set due to higher temperatures (data not presented) during the early part of the growing season. Night temperatures were higher the first 20 to 25 days after transplanting for the 1991 crop than for the 1992 crop. Rainfall distribution was not a problem, as supplemental irrigation was used during both years. Therefore, the reason for such a vast difference between years is not clear.

Total and marketable yields (Table 1) increased as plant spacing decreased from 2.2 to $0.9 \mathrm{~m}$. The yield component that contributed most to greater yields under high-density plantings was increased fruit count per unit land area. Average fruit weight decreased some as plant spacing decreased, but the magnitude of difference was inconsequential, except for the 1991 'Crimson Sweet' crop. Hence, 7410 plants/ha did not produce substantially smaller fruit than 3030 plants/ha. These results are consistent with previously reported plant-spacing responses of 'Charleston Gray' watermelon by Brinen et al. (1979), who reported a $13 \%$ to $14 \%$ reduction in average marketable fruit weight and a total marketable yield increase per unit land area of $37 \%$ to $48 \%$ when plant spacing was reduced from 2.4 to $0.6 \mathrm{~m}$.

Information concerning total and marketable yields traditionally is reported for many watermelon experiments. However, these data alone do not adequately describe fruit-weight distribution. Cumulative relative frequencies of watermelon fruit count over various fruitweight class intervals indicated that fruitweight distribution for a particular cultivar was similar, regardless of spacing or year (Fig. 1). One first-order logistic function was fitted to all distribution data for each cultivar. Data farthest from the average cumulative distribution line are the extremes of the experiment (i.e., the $0.9-\mathrm{m}$ plant spacing in $1991 \mathrm{vs.} \mathrm{the}$ 2.2-m plant spacing in 1992).

The closer plant spacings reduced total fruit weight and count per plant under some conditions (Table 2), as reported previously for watermelon and other vegetable crops (Brinenetal., 1979; Knavel, 1991; Staubetal., 1992; Stoffella and Bryan, 1988; Widders and Price, 1989). However, producers are not concerned with an individual plant's performance. Instead, their goal is to increase total marketable yield per unit land area in an economically efficient manner to boost gross returns. Gross returns for watermelon derived from

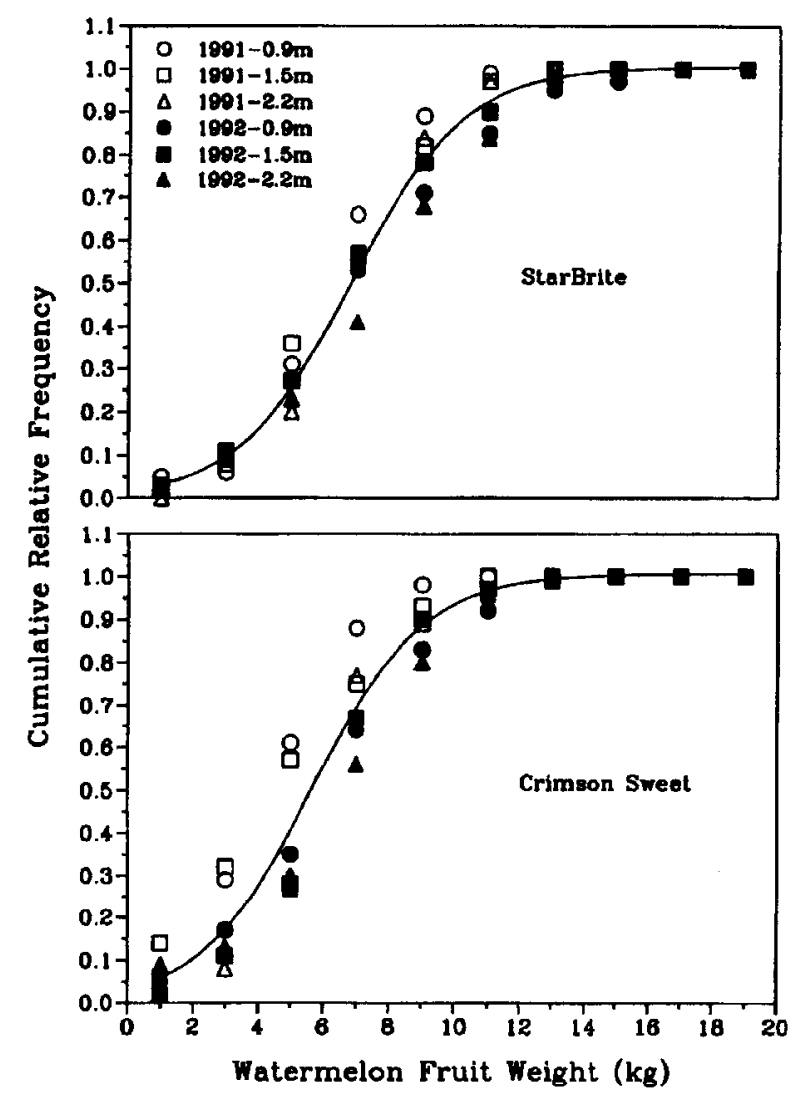

Fig. 1. Cumulative relative frequency of fruit count in various weight classes for 'StarBrite' and 'Crimson Sweet' watermelons grown in 1.5-m-wide rows with plant spacings of $0.9,1.5$, or $2.2 \mathrm{~m}$ during 1991 and 1992. The solid line is a fined, first-order logistic function for all data points for a particular cultivar. 
Table 2. Fruit count and fruit weight per plant for 'StarBrite' and 'Crimson Sweet' watermelons-grown-at three plant spacings during 1991 and 1992.

\begin{tabular}{|c|c|c|c|c|}
\hline \multirow{2}{*}{$\begin{array}{l}\text { Plant } \\
\text { spacing (m) }\end{array}$} & \multicolumn{2}{|c|}{ StarBrite } & \multicolumn{2}{|c|}{ Crimson Sweet } \\
\hline & 1991 & 1992 & 1991 & 1992 \\
\hline \multicolumn{5}{|c|}{ Fruit/plant } \\
\hline 0.9 & 1.5 & 2.7 & 0.8 & 2.5 \\
\hline 1.5 & 2.0 & 3.3 & 0.9 & 2.9 \\
\hline 2.2 & 2.1 & 4.3 & 1.2 & 3.6 \\
\hline Linear significance & NS & $* *$ & NS & $* * \cdots$ \\
\hline \multicolumn{5}{|c|}{ Fruit wt (kg/plant) } \\
\hline 0.9 & 9.9 & 21.9 & 3.8 & 17.9 \\
\hline 1.5 & 14.1 & 25.7 & 4.7 & 20.4 \\
\hline 2.2 & 15.2 & 37.0 & 7.6 & 18.1 \\
\hline Linear significance & NS & $* *$ & * & NS \\
\hline
\end{tabular}

Ns,*******Nonsignificant or significant at $P<0.05,0.01$, or 0.001 , respectively.

Table 3. Gross returns for 'StarBrite' and 'Crimson Sweet' watermelons grown at three plant spacings during 1991 and 1992.

\begin{tabular}{|c|c|c|c|c|}
\hline \multirow{2}{*}{$\begin{array}{l}\text { Plant } \\
\text { spacing }(\mathrm{m})\end{array}$} & \multicolumn{2}{|c|}{ StarBrite } & \multicolumn{2}{|c|}{ Crimson Sweet } \\
\hline & 1991 & 1992 & $1991^{z}$ & 1992 \\
\hline \multicolumn{5}{|c|}{$\$ / h a(1000 s)$} \\
\hline 0.9 & 6.5 & 15.2 & -- & 10.8 \\
\hline 1.5 & 5.7 & 13.6 & --- & 9.5 \\
\hline 2.2 & 4.9 & 11.7 & --- & 8.0 \\
\hline
\end{tabular}

yields estimated by regression, like those for cucumber derived by Cantliffe and Phatak (1975), indicate that returns increased with high-density plant populations (Table 3 ). The most significant additional input per unit land area for the grower is increased transplant or seed cost.

Additional research is needed to determine the carrying capacity or upper limit of yield response to plant population increases for 'Crimson Sweet', 'StarBrite', and other watermelon cultivars. However, these results indicate that, in terms of marketable yield and gross returns, a grower's advantage would reside in increasing plant populations if the current population being used is within 2500 to 3000 plants/ha. A grower may not want to increase plant population on a fixed acreage, however, since the market is finite. Instead, a grower may reduce acreage and use highdensity plantings to achieve similar production from fewer acres, a strategy resulting in savings on fertilizer, pesticides, machinery, and irrigation. Also, there would be less envi- ronmental exposure to chemicals and less total water used to grow the crop.

\section{Literature Cited}

Auld, B.A., K.M. Menz, and C.A. Tisdell. 1987. Weed control economics. Academic, Orlando, Fla.

Brinen, G.H., S.J. Locascio, and G.W. Elmstrom. 1979. Plant and row spacing, mulch, and fertilizer rate effects on watermelon production. J. Amer. Soc. Hort. Sci. 104:724-726.

Cantliffe, D.J. and S.C. Phatak. 1975. Plant population studies with pickling cucumbers grown for once-over harvest. J. Amer. Soc. Hort. Sci. 100:464-466.

Dweikat, LM. and S.R. Kostewicz. 1989. Row arrangement, plant spacing, and nitrogen rate effects on zucchini squash yield. HortScience 24:86-88.

Granberry, D.M. 1988. Culture, p. 5-8 In: W.O. Mizelle, Jr. (ed.). Commercial watermelon production. Univ. of Georgia, Athens, Coop. Ext. Serv. Publ. B-996.

Granberry, D.M., P. Colditz, and W.J. McLamin. 1986. Watermelon: Commercial vegetable production. Univ. of Georgia, Athens, Coop. Ext. Serv. Circ. 466.
Hall, A.E. 1990. Physiological ecology of crops in relation to light, water, and temperature, p. 191234. In: C.R. Carroll, J.H. Vandermeer, and P.M. Rosset (eds.). Agroecology. McGraw-Hill, New York.

Harper, J.L. 1977. Population biology of plants. Academic, New York.

Hurst, W.C:1988. Harvest and handling, p. 28-32. In: W.O. Mizelle, Jr. (ed.). Commercial watermelon production. Univ. of Georgia, Athens, Coop. Ext. Serv. Publ. B-996.

Knave], D.E. 1991. Productivity and growth of short-internode muskmelon plants at various spacings or densities. J. Amer. Soc. Hort. Sci. 116:926-929.

Mizelle, W.O., Jr. 1990. Vegetable economics: A planning guide for 1990. Univ. of Georgia, Athens, Coop. Ext. Serv. Misc. Publ. 258.

Mundt, C.C. 1990. Disease dynamics in agroecosystems, p. 263-299. In: C.R. Carroll, J.H. Vandermeer, and P.M. Rosset (eds.). Agroecology. McGraw-Hill, New York.

Pant, M.M. 1979. Dependence of plant yield on density and planting pattern. Ann. Bot.44:513-516.

Power, A.G. and P. Kareiva. 1990. Herbivorous insects in agroecosystems, p. 301-327. In: C.R Carroll, J.H. Vandermeer, and P.M. Rosset(eds.) Agroecology. McGraw-Hill, New York.

Stang, J.R., H.J. Mack,and K.E.Rowe. 1979. Quantitative relation of bush snap bean (Phaseolus vulgaris L.) yields to plant population density. J. Amer. Soc. Hort. Sci. 104:873-875.

Staub, J.E..L.D. Knerr, and H.J. Hopen. 1992. Plant density and herbicides affect cucumber productivity. J. Amer. Soc. Hort. Sci. 117:48-53.

Stoffella, P.J. and H.H. Bryan. 1988. Plant population influences growth and yields of bell pepper. J. Amer. Soc. Hort. Sci. 113:835-839.

Stoffella, P.J., S.J. Locascio, P.H. Everett, T.K. Howe, J.W. Scott, and S.M. Olson. 1988. Yields of two tomato cultivars differing in shoot growth at several plant populations and locations. HortScience 23:991-993.

Thomley, J.H.M. 1983. Crop yield and planting density. Ann. Bot. 52:257-259.

Weiner, J. 1990. Plant population ecology in agriculture, p. 235-262. In: C.R. Carroll, J.H. Vandermeer, and P.M. Rosset (eds.). Agroecology. McGraw-Hill, New York.

Widders, I.E. and H.C. Price. 1989. Effects of plant density on growth and biomass partitioning in pickling cucumbers. J. Amer. Soc. Hort. Sci. 114:751-755.

Willey, R.W. and S.B. Heath. 1969. The quantitative relationships between plant population and crop yield. Adv. Agron. 21:281-321.

Zimdahl, R.L. 1980. Weed-crop competition: A review. Intl. Plant Protection Ctr., Oregon State Univ., Corvallis. 